\title{
Преписивачка делатност у манастирима Карловачке митрополије у 18. веку
}

\author{
Жарко Војновић \\ Народна библиотека Србије, Београд \\ stevlovi@gmail.com
}

\begin{abstract}
Сажетак
Рад се бави преписивачком делатношћу манастира Карловачке митрополије у 18. столећу као одразом средњовековне традиције. Пошто је укратко анализирана карактеристична историјска ситуација, наведени су разлози и сврха настављања преписивања у то време. Разматрају се интензитет и распрострањеност преписивачке праксе, врсте преписиваних књига (богослужбене, богословске, историографске, школске итд.), фреквентност преписивачког рада у току столећа, као и обичај компилирања личних зборника и њихово место у манастирским библиотекама. Наводе се и преписивани наслови, типични за овај период, при чему има књига српског, руског и западноевропског порекла. Нарочито се подвлачи пракса преписивања оригиналних дела српске средњовековне књижевности, како литургијских, тако и историографских. Појава новог типа школства код Срба илустрована је обичајем преписивања школских уџбеника. Посебно су наглашене и везе са руском културом, која је, између осталог, имала и посредничку улогу. На крају је дат кратак преглед и оцена дела рукописне збирке манастира Грабовца, везане за овај период, при чему је више пажње усмерено на полемичку теолошку литературу.
\end{abstract}

Кључне речи: рукописне књиге, преписивање, манастири, Карловачка митрополија, 18. век, манастирске библиотеке, рукописна збирка манастира Грабовца

Класични период историје српске књиге везан је пре свега за традицију писања и преписивања. Без обзира да ли се ради о писању - стварању оригиналног дела, или преписивању - умножавању већ постојећег, ${ }^{1}$ то време, које у историјској периодизацији спада углавном у средњи век, продужава се, силом историјских околности, и у епохи штампане књиге. Недовољан број књига које је произвело рано српско штампарство проузроковао је настављање праксе писања и преписивања. Она је присутна чак и кад српска богослужбена места, на првом месту манастири, почну убрзано увозити руску штампану књигу, то јест у 17 . веку. Ситуација се драстично не мења ни на граници векова. ${ }^{2}$ Иако се статистички без већих напора може утврдити да удео српске рукописне књиге, како расте увоз руске штампане, у укупном фонду све више опада, њена производња још дуго неће престати. Очигледно да, без обзира на то што се примат штампане књиге одавно не доводи у питање, није могуће на тај начин задовољити све потребе. Овде се поставља неколико питања на која није увек лако одговорити. Да ли је увоз руске штампане књиге у 18 . веку био у бројчаном смислу довољан? Да ли су се у датом тренутку могле набавити све нужне књиге? Да ли су штампане књиге садржале све врсте текстова

\footnotetext{
1 Ову поделу дајемо из методолошких разлога. У традиционалном смислу, она је много мање изражена но данас, због другачије свести о улози аутора.

2 Можда изненађује чињеница да је иста ситуација у то време била и у Русији, где је ипак штампарство било врло развијено: „Книгопечатание не только не прекратило практику переписки книг, но, по-видимому, и не сократило ее размеры. И в XVII, и даже в XVIII в. переписывание книг продолжалось, хотя, как мы знаем, число выходивших в России книг непрерывно росло." (Сергей Павлович Луппов, Книїа в России в XVII веке (Ленинград: Наука, 1970), 37). Пошто се ради о истом културном кругу, и пошто су и руске манастирске библиотеке имале сличне потребе као и српске, очигледно да су поједини узроци настављања производње рукописне књиге такође слични.
} 
потребних српским манастирским библиотекама? Да ли су српски манастири - или њихови приложници - увек били финансијски кадри да обезбеде потребне књиге? Да ли су постојале специфичне потребе српског друштва у Карловачкој митрополији 18. века, па према томе и манастира, које штампана руска књига није могла покрити?

На ова питања могу се ипак дати релативно задовољавајући одговори, изврши ли се макар и летимична анализа писаних/преписиваних књига. На првом месту, мора се свакако проверити има ли међу преписиваним књигама богослужбених, тј. оних које се преписују зато што спадају у манастирски богослужбени минимум. Увид у збирке записа и саме библиотеке сведочи да се током целог 18. столећа та пракса наставља, иако ниским интензитетом. Међутим, тај податак важан нам је како бисмо посредно покушали протумачити тадашњу ситуацију. Ако се богослужбене књиге још увек понегде преписују, то значи да оне у штампаном облику нису увек и на сваком месту биле доступне појединим манастирима: могуће је да су биле прескупе, а да манастир сам није тренутно имао новца да их купи, или се није пронашао нико ко би их приложио; могуће да их уопште у датом тренутку и није било на тржишту, а није далеко ни могућност да неке од књига потребних српским манастирима у Русији никада и нису биле штампане. У првој четвртини века преписивања богослужбених књига било је, рецимо, у Великој Ремети: 1702. преписан је један требник, ${ }^{3}$ један минеј $1707,{ }^{4}$ а 1723 . синаксар; ${ }^{5}$ касније ће (1764) бити преписана и „књига канона на осам гласова“. ${ }^{6}$ Слично је, рецимо, било и са манастиром Крушедолом, где је преписана једна књига са чином освећења цркве (1749), ${ }^{7}$ а потом и "Чин бивајеми на основаније церкви“. ${ }^{8}$

Богослужбене књиге општег типа представљају мањину, узмемо ли у обзир све рукописне књиге настале у 18. веку по манастирима Карловачке митрополије. Ипак, било је и другачијих текстова потребних за богослужење, до којих се није могло доћи другим путем до писањем и преписивањем. Од њих можемо поменути случај преписивања тзв. Јаковљеве литургије 1751. у Шишатовцу, ${ }^{9}$ што је свакако знак да ова литургија није код нас била непозната. Већина, међутим, богослужбених састава које је требало преписати ради кориштења, готово по правилу, представљају они којих није било у руским штампаним књигама, а тичу се историје и традиције Пећке патријаршије. Најпознатији је случај Србљака, који у данашњем облику настаје у српској монашкој средини, манастиру Раковцу, почетком 18. века, како би се надокнадио недостатак служби српским светитељима, које руске књиге нису садржале, ${ }^{10}$ а који је у 18 . веку двапут штампан (у Римнику 1761. и Венецији 1765). ${ }^{11}$ Осим Србљака, било је доста случајева преписивања појединачних служби српским светитељима. Најкарактеристичнији је случај Крушедола, који је, као „деспотска“ обитељ, нарочито морао бити заинтересован за службе

\footnotetext{
3 Љубомир Стојановић, Сйари срӣски зайиси и найӣиси, 1-6 (Београд: САНУ; Народна библиотека Србије, 1982-1988), 7284 (У даљем тексту: ССЗН).

${ }^{4} \mathrm{CC} 3 \mathrm{H}, 2165$.

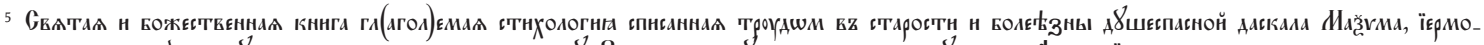

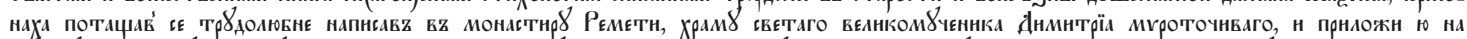

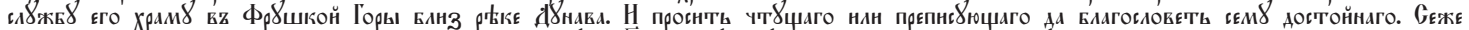

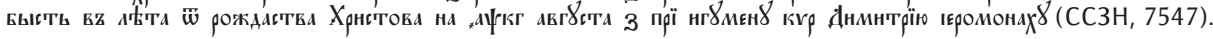

${ }_{6}^{6} \mathrm{CC} 3 \mathrm{H}, 3239$.

7 Сава Петковић, Ойис рукойиса манасиира Крушеgола (Сремски Карловци: Монашко удружење православне српске Митрополије карловачке, 1914), број јединице (у даљем тексту: бр.) 33.

8 Исто, бр. 34.

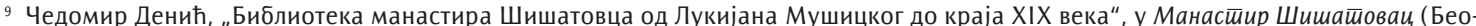
град: САНУ; Нови Сад: Матица српска, 1989), 401. Осим овога, преписивали су се и други мањи богослужбени текстови, попут службе светој Петки (Фенек, 1777 - ССЗН, 8473) и чина погребења монаха (Раковац, 1779 - ССЗН, 8520). Тешко је рећи зашто је долазило до преписивања оваквих текстова, који су се иначе налазили у редовним црквеним књигама.

${ }^{10}$ О проблему србљака у 18. веку: Лаза Чурчић, „Србљаци у XVIII веку“, у Срйске књиіе и срйски йисии 18. века (Нови Сад: Књижевна заједница Новог Сада, 1988), 32-62.

11 Да су се службе српским светитељима пре тога преписивале у неком обиму, говори и податак о неименованом монаху који 1757. долази у Хопово баш са тим циљем, „ради преписанија правила светих отец сербских“ (СС3Н, 8114).
} 
светим Бранковићима. Тако се године 1720. у том манастиру појавио препис опште службе "светим деспотима“, писан српском рецензијом, са посветом митрополиту Викентију Поповићу. ${ }^{12}$ Потом је, око половине века, настао препис службе светом Јовану Деспоту, светим Атанасију и Кирилу Александријским, као и светом Максиму архиепископу, „деспоту српском“; препис садржи и Максимов животопис. ${ }^{13}$ Осим ове збирке служби, негде у исто време у Шишатовцу бива преписана и служба цару Урошу са његовим житијем, дело патријарха Пајсија Јањевца, која се касније затекла у Крушедолу. ${ }^{14}$

Подразумевало се да ће се, из разлога очувања те традиције, преписивати и друге књиге, које нису богослужбене, али их такође нема увек по руским штампаним књигама, као што је житије Светог Саве. Средином века у Кувеждину настаје један препис, који се касније нашао у манастиру Крка, ван граница Митрополије. ${ }^{15}$ Тих година (1756) Савин животопис преписује се и у Ремети; веза са средњовековним предањем чува се, између осталог, и чињеницом што је преписан са „древног“ рукописног оригинала.

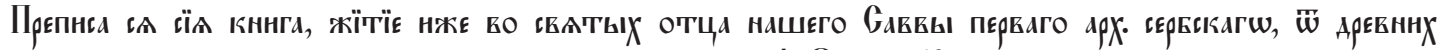

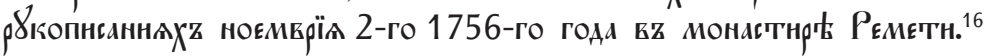

Готово истовремено, заповешћу митрополита Павла Ненадовића, исто житије преписује се и у његовој резиденцији у Карловцима. Ово јасно говори да се у то време јавља историцистички национални интерес, јер житије Светог Саве очигледно постаје обавезна литература у монашким круговима, одакле ће се овај култ снажније преносити у народ. Јаче буђење занимања за националне теме сведоче још неки значајни преписи. Везу са изворном Србијом и класичним предањем остварује и игуман Врдника Стефан Зорановић, који са оригинала нађеног код познатог у то време духовника Константина Студеничанина преписује „историју сербски(х) цареј" (1764). ${ }^{17}$ Занимљив подухват сличног усмерења организује се 1774. у Крушедолу, где се преписују Славеносрйске хронике „из оригинала Георгија Бранковича историје“, и то у три тома. ${ }^{18}$ Овај обимни текст грофа Георгија Бранковића, несуђеног деспота Илирика, који је у целом 18. веку уживао изузетно поштовање, схватан је као ризница националних идеја, које су се у то време програмски развијале у Карловачкој митрополији упркос германизацији систематски спровођеној у време Марије Терезије, због чега се морао наћи и у општежитијима као центрима очувања и развоја националне свести. ${ }^{19}$

Оно што је специфичност рукописне традиције 18. века јесте преписивање текстова богословског садржаја и то најчешће оних који су плод руског академског богословља 17. и 18. века. Нова руска теолошка мисао у то време је представљала стандард у Карловачкој митрополији, што сведочи велики број руских штампаних књига тог порекла пронађених у манастирским библиотекама (па и шире): манастирске збирке су на тај начин покушавале да буду савремене, па макар и традиционалним и несавременим методом преписивања, уколико се до оригиналних књига није могло доћи у потребном броју примерака, или су биле прескупе.

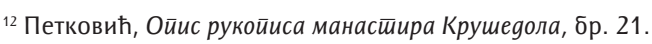

${ }^{13}$ Исто, бр. 20

${ }^{14}$ Исто, бр. 22. Службе Бранковићима преписивале су се и ван манастира. Један такав рукопис, који је садржао службе Максиму деспоту, Ангелини деспотици, Стефану деспоту и Јовану деспоту, сачинио је 1740. у Новом Саду свештеник Илија Стојковић; незнаним путем рукопис је стигао у Далмацију, у манастир Драговић: Vladimir Mošin i Milan Radeka, „Ćirilski rukopisi u sjevernoj Dalmaciji“, Starine JAZU br. 48 (1958): 206.

15 Isto, 196 (бр. 28). Препис је из 1752, садржи 142 листа.

${ }^{16} \mathrm{CC} 3 \mathrm{H}, 3098$

${ }^{17} \mathrm{CC} 3 \mathrm{H}, 3240$.

${ }^{18} \mathrm{CC} 3 \mathrm{H}, 3413,3414,3435$

${ }^{19}$ Неименована „историја“, која се 1769. године преписује у Ремети, „повељенијем пречесњејшаго господина Атанасија Исаијевића“, вероватно такође спада у корпус националних текстова.
} 
Оне су, осим тога, представљале обавезну монашку образовну литературу, због чега су просто морале наћи своје место у манастирима. Преписивањем тако настаје додатни део „књига за читање".

Иако нема црте суштинске оригиналности, ова активност није се одвијала на једнаком нивоу. Методолошки је можемо поделити на механичку и креативну. У прву групу спадало би пуко преписивање са руских предложака. Друга група укључује оне литерарне саставе у којима налазимо приређивачки рад, тј. свестан одабир и комбиновање материјала. Ова подела није апсолутна, а у оба случаја подразумева се избор.

Врло често се у првом случају ради о популарним или тренутно траженим и актуелним издањима. Тако је у манастиру Кувеждину настао препис познатог у оно доба и објављеног у Венецији дела Орйоgоксос омолоїија, ${ }^{20}$ предвиђеног као основно образовно штиво у време почетка просветних реформи митрополита Павла Ненадовића. Сличној атмосфери припада и књига приписана најважнијем теологу петровске епохе Теофану Прокоповичу, чији је препис (руком Крсте Манојловића) финансирао месићки јеромонах Пахомије Јанковић, а наслов је Душевноје зери,ало, јеже јесш закон Божији. ${ }^{21}$ Амблематско-поетски зборник

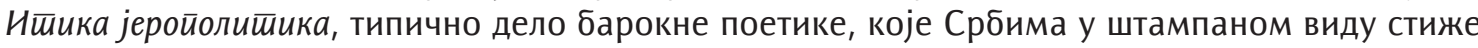
из Русије, а потом се прештампава и код нас, нашло је такође свог преписивача у манастиру Кувеждину. 22 Јован (у монаштву хаџи Исидор) Дамјанов (Дамјановић), из чије је руке овај препис изашао, пренео је у српске манастире и дело светог Димитрија Ростовског

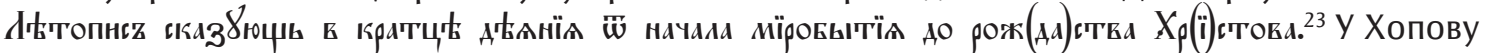
је Василије Недељковић преписао, са руске штампане књиге, у 18. веку код нас чувено дело

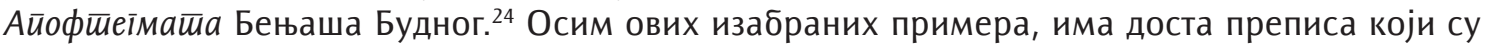
очигледно руског порекла, али им није лако установити оригинал, нити да ли су дословно сачињени према изворнику. ${ }^{25}$ Занимљивост је и постојање преписа неправославног теолошког порекла, попут дела евангеличког теолога Данијела Хајнриха Пурголда у Крушедолу. ${ }^{26}$ Ипак, нису се преписивала само богословска дела, нити она духовне инспирације. До наших манастирских библиотека стизали су западни аутори у руском преводу, па се дешавало и да се они преписују у недостатку оригиналних издања, као што је у Гргетегу настао препис географског дела Јохана Хибнера.. 27

Огроман утицај на избор материјала за преписивање имала је околност да се међу Србима тог доба јављају прве школе, као и да се похађају оне у Русији, на првом месту у Кијеву, што се није могло извести без уџбеника. Први међу њима били су свакако руског порекла, а онда настају и српски. Од њих по свом значају без премца је Ейишом Дионисија Новаковића, који је кориштен као уџбеник у новосадским богословским школама, а пошто је од његовог настанка до објављивања протекло више од четврт века, у међувремену је преписиван: у манастирима

\footnotetext{
${ }^{20}$ Сава Петковић. Манасиир Кувежgин и Дивща у XVIII веку (Нови Сад: Натошевић, 1936), 32.

${ }^{21} \mathrm{CC} 3 \mathrm{H}, 8666$. Књига је нађена у манастиру Раковац.

22 Петковић, Манасиир Кувежяин и Дивша, 33.

${ }^{23}$ Исто.

${ }^{24}$ Тихомир Остојић, Досишеј Обраgовић у Хойову (Нови Сад: Матица српска, 1907), 363. Ако нису сами преписивали, монаси су се умели потрудити да преписе важних књига, којих није било штампаних на српском (рускословенском), задобију за манастирске библиотеке. Тако је у Крушедол 1753. пристигао препис (који је сачинио земунски свештеник Стојан Петров 1739) познатог дела Агапија Ландоса Грешних сйасеније у словенском преводу Самуила Бакачича. С. Петковић, Ойис рукойиса манасйира Крушедола, бр. 64.

${ }^{25}$ Манастирске збирке Карловачке митрополије биле су пуне руских издања беседа отаца Цркве, пре свега Јована Златоуста, а потом Јефрема Сиријског, Григорија Богослова, Аве Доротеја итд., уз знатан број књига новијих руских теолога. Уз тај материјал свакако да није било немогуће саставити зборник по сопственом нахођењу, а ако су биле потребне националне теме, могли су се наћи и оригинални српски рукописи, које је само требало језички саобразити новом рускословенском стандарду.

${ }^{26}$ Петковић, Ойис рукойиса манасииира Крушеgола, бр. 66.

${ }^{27} \mathrm{CC} 3 \mathrm{H}, 8430$. Наслов руског посредника је: Земновоgнаїо круїа крат̄кое ойисание из стиарыя и новыя іеоїрафии (старањем Петра Великог издато у Москви 1719).
} 
га налазимо у виду самосталне рукописне публикације, као у Кувеждину ${ }^{28}$ или Месићу, ${ }^{29}$ или у склопу разних зборника, као у Крушедолу, Хопову ${ }^{30}$ и Ораховици; ${ }^{31}$ ова два последња осим њега садрже и Новаковићеву Пройеgujу, ${ }^{22}$ такође богословски састав уџбеничког карактера.

Креативнији вид стварања рукописних књига у 18. веку налазимо у пракси састављања зборника, врло честој у манастирима Карловачке митрополије. Очигледно да образованијим и вреднијим монасима нису биле довољне готове штампане књиге како би исказали своја духовна и интелектуална стремљења, па су се старали да праве компилације по својим потребама и укусу. Осим тога, свакако да део разлога лежи и у чињеници да се све потребне књиге ни у ком случају нису могле наћи у једном манастиру, због чега су монаси можда и бивали приморани да праве рукописне изводе из књига које су сматрали важним, а сами их нису лично поседовали, или су их можда могли тек привремено позајмити с неког другог места. У принципу, састављање зборника који су садржали, рецимо, беседе разног порекла, јесте наслеђен обичај, а у 18. веку је специфично то што у се њих укључују текстови из руских штампаних књига, без обзира да ли су они класичног патролошког или нововековног руског порекла. На тај начин су манастирске библиотеке превазилазиле могућности које је нудило тржиште, а такође излазиле и из оквира сопствених могућности, стварајући додатни квалитет. Као илустрацију можемо навести хоповске зборнике, познате још од чувене књиге Тихомира Остојића о Доситеју Обрадовићу. Први је саставио неформални учитељ Доситејев, хоповски јеромонах (касније игуман) Василије Недељковић: тај зборник је у ствари избор из две врло популарне и раширене књиге Симеона Полоцког Обеg gушевни и Вечера gушевна, ${ }^{33}$ које често налазимо по српским манастирима. ${ }^{34}$ Из њих се у Хопову читало у цркви. ${ }^{35}$ Други зборник је, како каже Остојић, "читава мала енциклопедија знања“, на преко хиљаду страна, са око 120 посебних чланака. Његов творац је хоповски монах Спиридон, који је показао широк интелектуални интерес.

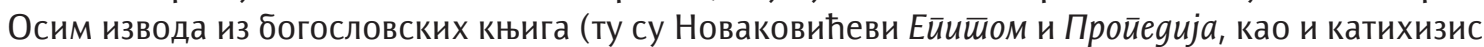
руског учитеља В. Крижановског), он је у њега укључио и текстове историјске садржине (између осталог, део Хроника грофа Бранковића, народне српске привилегије, неколико текстова из Баронија), дидактичке саставе, па и оне чисто литерарне садржине, Езопове басне, а потом и дела из географије. Зборник се окончава Јустинијановим и Душановим законицима. ${ }^{36}$ Важност оваквих састава разуме се сама по себи: образованији монаси на тај су начин пружали могућност онима који су били заинтересовани, а сами нису били вешти, да на једном месту дођу не само до основних (и то солидних) теолошких знања, него и до општих, која су спадала, најчешће преко руског посредника, у обавезну литературу српског интелектуалца. Записи о томе ко је зборник прочитао сведоче да се не ради само о монасима, ${ }^{37}$ па манастирске библиотеке и на овај начин добијају нијансу јавности. Наравно, слабост оваквих компилација је у чињеници да се ради о уникатима и да је њихово кориштење ограничено на један простор.

\footnotetext{
${ }^{28}$ Петковић, Манасӣир Кувежяин и Дивша, 32. О Ейишему више код: Лаза Чурчић, „Популарност и неки проблеми ширења Епитома Дионисија Новаковића“, у Срйске књиіе и срйски йисии 18. века, 76-92.

${ }^{29} \mathrm{CC} 3 \mathrm{HB}, 8420$. Овај је припадао иришком протопрезвитеру Андреју Шакабенти, рођеном брату патријарха Арсенија IV. У Месић је доспео вероватно преко његовог сина, Јосифа Јовановића Шакабенте, вршачког епископа и обновитеља тог манастира.

${ }^{30}$ Остојић, Досишеј Обраяовић у Хойову, 360

${ }_{31}$ Радослав М. Грујић, Србуље у бившем Вараждинском іенералашиу и Славонији (Загреб: Просвјета, 2016), $265-267$.

${ }^{32}$ Vladimir Mošin, Stari rukopisi Srba u Hrvatskoj od XIII do XX stoljeća (Zagreb: Povijesni muzej Hrvatske, 1970), br. 57. Преписи овог дела забележени су и у Далмацији -у манастирима Крка (Mošin i Radeka, „Ćirilski rukopisi...": 198) и Драговић (Isto: 206), што је јасан знак да се богословска образованост из Карловачке митрополије ширила и ван њене јурисдикције, стварајући и на тај начин јединствен духовни простор.

33 Остојић, Досийеј Обраяовић у Хойову, 349

${ }^{34}$ Види: Жарко Војновић, „Ко је аутор књиге 'Стихи о недељи' (Беч, 1792)?“, Брайсииво бр. 19 (2015): 151-166.

${ }^{35}$ Василије Недељковић је састављач и зборника који се налазио у Крушедолу, са неколико теолошких текстова, између осталога очигледно и Ейийомом (којег Сава Петковић није препознао) - Петковић, Ойис рукойиса манасйира Крушеgола, 198

${ }^{36}$ Остојић, Нав. дело, 350-359.

${ }^{37}$ Исто, 377.
} 
Процес стварања рукописних књига за манастирске библиотеке укључује у себе још неке аспекте, од којих је можда најважнији превођење. Узмемо ли у обзир чињеницу да је велики део оваквих зборника руског порекла, треба имати у виду да ти текстови нису преузимани у потпуности дословно. Иако се рускословенски језик, који се у Карловачкој митрополији званично користи још од почетка друге четвртине 18. века, сматрао заједничким, интернационалним те у неку руку и српским, због практичних разлога он се посрбљивао, нарочито тамо где је у изворном тексту превласт задобијао руски народни језик. Поменути хоповски зборници, нарочито Спиридонов, представљају посрбе у том смислу. Ипак, има и потпуних превода који се јављају у рукописима. Добар пример је у то доба веома цењено полемичко дело Илије Минијата Камен саблазни, које је у Фенеку превео са грчког изворника Викентије Ракић. ${ }^{38}$

Колико је жива била преписивачка делатност, а донекле и оригинална или барем компилаторска ауторска у то време, може се видети на примеру манастира Грабовца, где је сачуван знатан број рукописа из 18. века. За многе од њих се зна да су настали у самом манастиру, а други су тамо пристигли заједно с монасима који су у њему боравили. И једни и други добро осликавају културну и интелектуалну климу времена. Притом, можемо чак и заобићи типску врсту рукописних књига као што су поменици, тефтери, „парусије“ (пописи приложника за које се служи литургија) итд., које налазимо по свим манастирима о којима се у овом раду говори, јер или представљају последицу административног деловања манастирских власти, или нису органски део манастирске библиотеке попут богослужбених или књига за читање. Рукописне књиге Грабовца тачно показују шта је занимало човека духовних интересовања 18. века, којима се додају и општекултурна. Уз неколико богослужбених књига, какве налазимо и на другим местима, ова манастирска збирка поседује и класичне мешовите рукописне зборнике литургијских и богословских текстова, ${ }^{39}$ уобичајене зборнике беседа, ${ }^{40}$ публикације са систематским излагањем неког богословског питања као што је један спис о светим тајнама, ${ }^{41}$ у то време

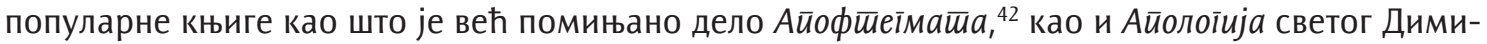
трија Ростовског, омиљеног савременог теолога. Нарочито се грабовачка библиотека одликује колекцијом теолошке литературе полемичког карактера, без које се није могла замислити

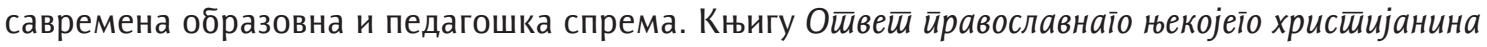
Никифора Теотокиса сусрећемо у чак три различите рукописне варијанте, ${ }^{43}$ што нам говори да се у манастиру вероватно свесно радило на развоју полемичког богословља у средини сасвим ненаклоњеној православнима. То потврђује и препис антикатоличког (и антикијевског) трактата Мечеи, gуховни 44 браће Лихуд, чувених грчких учитеља који су у последњој четвртини 17. и почетком 18. века радили у Москви. За нас је особито важно што један од преписа сведочи о живом присуству српске богословске школе, чији су се производи ширили најчешће баш у преписима (и до данас нажалост нису издати), као што је Бесириситраснаја исйорическа

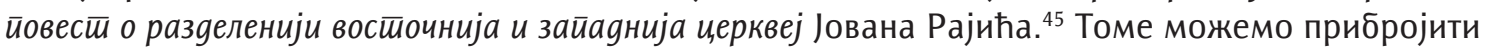
и рукописе који припадају највероватније перу Дионисија Новаковића, ${ }^{46}$ који је део живота

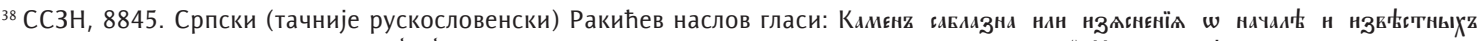

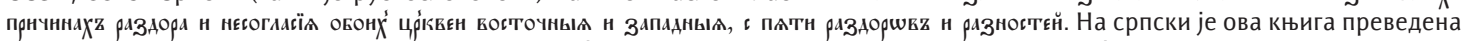

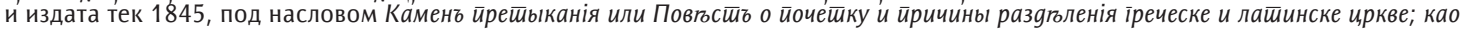
и о иеейь иррейираиелны войроса, у коима се не соїлашаваю.

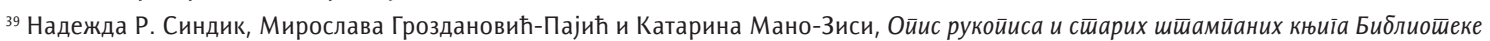
Срйске йравославне ейархије буgимске у Сенйанgреји (Београд: Народна библиотека Србије; Нови Сад: Матица српска, 1991$),$ бр. 38.

${ }^{40}$ Исто, бр. 27. Овде је највероватније преписана нека руска штампана књига.

${ }^{41}$ Исто, бр. 22. И овом случају очигледно се ради о препису неког руског штампаног оригинала.

${ }^{42}$ Исто, бр. 23. Овај је препис настао у новосадском богословском семинару.

${ }^{43}$ Исто, бр. 31, 32, 84

${ }^{44}$ Исто, бр. 16

${ }^{45}$ Исто, бр. 29.

${ }^{46}$ Нсто, бр. 30.
} 
провео баш као епископ Будимске епархије, окончавши новосадску професорску каријеру. Можда баш са њом има везе чињеница да је у Грабовцу сачуван известан број оновремених уџбеника који су се користили управо у тим школама. Њихов највећи део дело је, очигледно и заоставштина, игумана Арсенија Теофановића, који их је тридесетих или четрдесетих година преписивао у Покрово-богородичној школи у тадашњем Петроварадинском Шанцу, каснијем Новом Саду: Уибеник лоїике и философије, Философски сйиси, Ойшйа философија и мешиафизика, Лоїика, Алїебра и йриїономеширија. ${ }^{47}$ Занимљиво је и да су неки преписи настали и за потребе образовања грабовачких монаха; њих је по благослову игумана сачинио јерођакон Данил. ${ }^{48}$

Можда најпознатији, међутим, рукопис сачуван у манастиру је Грабовачки лейойис, ${ }^{49}$ настао у традицији средњовековног жанра, један од ретких летописа сачуваних из тог времена. ${ }^{50}$ И на крају овог прегледа рукописа манастира Грабовца 18. века, треба се свакако вратити на националне богослужбене теме, чији је најбољи израз тзв. Србљак Анйонија Грабовачкої, који је настајао током година у манастирима Раковцу, Шишатовцу и на крају довршен баш у Грабовцу, са службама српским светитељима. ${ }^{51}$ Осим њега, класичан је и пример рукописне службе локалном српском светитељу, Стефану Штиљановићу. ${ }^{52}$ Са свим овим књигама грабовачка библиотека свакако представља квинтесенцију рукописне праксе свог времена, једнако по интересовањима као и по достигнућима.

Иако је преписивање књига у 18 . веку било свакако периферни вид попуњавања манастирских библиотека на територији Карловачке митрополије, оно је важно јер представља још увек живу традицију, мада већ веома ослабљену, и јасну везу са средњим веком. Са друге стране, труд да се до књига дође на било који начин, па макар и тај анахрони, као и да се стварају компилације према специфичним потребама, сведочи о жељи монаха да своје личне, а и манастирске библиотеке, непрестано обогаћују, а уз то да врше и духовни утицај на своју хришћанску околину.

\section{Литература и извори:}

1. Čurčić, Laza. „Popularnost i neki problemi širenja Epitoma Dionisija Novakovića“. U Srpske knjige i srpski pisci 18. veka, 76-92. Novi Sad: Književna zajednica Novog Sada, 1988.

2. Čurčić, Laza. „Srbljaci u XVIII veku“. U Srpske knjige i srpski pisci 18. veka, 32-62. Novi Sad: Književna zajednica Novog Sada, 1988.

3. Denić, Čedomir. „Biblioteka manastira Šišatovca od Lukijana Mušickog do kraja XIX veka“. U Manastir Šišatovac, 397-409. Beograd: SANU; Novi Sad: Matica srpska, 1989.

4. Grujić, Radoslav. Srbulje u bivšem Varaždinskom generalatu i Slavoniji. Zagreb: Prosvjeta, 2016.

5. Jovanović, Tomislav. "Letopis manastira Grabovca“. Istočnik br. 9 (1994): 30-34.

6. Krasić, Vladimir. „Manastir Grabovac u budimskoj eparhiji“. Letopis Matice srpske br. 126-128 (1881).

7. Луппов, Сергей Павлович. Книїа в России в XVII веке. Ленинград: Наука, 1970.

8. Mošin, Vladimir. Stari rukopisi Srba u Hrvatskoj od XIII do XX stoljeća. Zagreb: Povijesni muzej Hrvatske, 1970.

\footnotetext{
${ }^{47}$ Исто, бр. 46-50.

${ }^{48}$ Исто, бр. 25, 36, 37. Све три књиге су граматике словенског језика: прва је препис једног руског уџбеника, а друга је компилација Арсенија Теофановића. Трећој извор није познат.

${ }^{49}$ Исто, бр. 52.

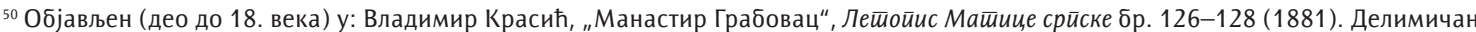
превод Томислава Јовановића на савремени српски: „Летопис манастира Грабовца“, Нсшиочник бр. 9 (1994): 30-34.

${ }^{51}$ Синдик, Гроздановић-Пајић и Мано-Зиси, Ойис рукойиса..., бр. 28.

${ }^{52}$ Исто, бр. 35. Ради се о служби преноса моштију.
} 
9. Mošin, Vladimir i Milan Radeka. „Ćirilski rukopisi u Sjevernoj Dalmaciji“. Starine JAZU br. 48 (1958): 189-215.

10. Ostojić, Tihomir. Dositej Obradović u Hopovu: studija iz kulturne i književne istorije. Novi Sad: Matica srpska, 1907.

11. Petković, Sava. Manastir Kuveždin i Divša u XVIII veku. Novi Sad: Natošević, 1936.

12. Petković, Sava. Opis rukopisa manastira Krušedola. Sremski Karlovci: Monaško udruženje pravoslavne srpske Mitropolije karlovačke, 1914.

13. Sindik, Nadežda R., Miroslava Grozdanović-Pajić i Katarina Mano-Zisi. Opis rukopisa i starih štampanih knjiga Biblioteke Srpske pravoslavne eparhije budimske u Sentandreji. Beograd: Narodna biblioteka Srbije; Novi Sad: Matica srpska, 1991.

14. Stojanović, Ljubomir. Stari srpski zapisi i natpisi, 1-6. Beograd: SANU; Narodna biblioteka Srbije, 1982-1988.

15. Vojnović, Žarko. „Ko je autor knjige 'Stihi o nedelji' (Beč, 1792)?”. Bratstvo br. 19 (2015): 151-166.

\title{
Copying Activity in Monasteries on the Territory of the Metropolitanate of Karlovci in the $18^{\text {th }}$ Century
}

\begin{abstract}
Summary
Although it was not typical for the rest of Europe in the $18^{\text {th }}$ century, copying was still present in Serbian monasteries of that time, including those on the territory of the Metropolitanate of Karlovci. This was caused by the lack of a stable market in the field of printed books, the content shortcomings of new Russian books, and the lack of financial resources. It was not rare that due to that fact even books of theology, which were imported from Russia massively, especially in the first half of the century, were copied. Copying the services for Serbian saints that did not exist in the new Russian books, as well as the national biographical and historiographical literature, from the biography of Saint Sava to the Chronicles of Count Georgi Branković, was the characteristic of the Serbian monasteries. The monks testify to their attachment to modern trends by frequently copying the works of academic Russian theology of the $17^{\text {th }}$ and $18^{\text {th }}$ centuries, which represent the standard educational literature of that period. Russian culture was also a mediator between the Serbian and West European cultures, so the books of non-Orthodox authors were copied in Russian translations as well. The emergence of a new school system with the Serbs after the Russian model is illustrated by the widespread practice of copying theological school textbooks, among which the most significant is Epitome by Dionysius Novaković. A large number of copied works of the Orthodox polemic anti-Catholic literature, both Greek and Russian and Serbian, which is certainly a feature of theology of this time and the result of academic education, should be observed in this context. As a consequence, there were numerous copies of textbooks on nontheological subjects studied in the schools of Novi Sad and Sremski Karlovci, which shows that the monks of the Metropolitanate of Karlovci became more and more educated. A more creative way of dealing with copying books, as a reflex of medieval practice, was composing personal anthologies. They were mostly compilations of texts from Russian printed books, which contained, in addition to the works of recent Russian theology, a lot of works from the patristic period, as well as historiographical, pedagogical, legal or literary texts. An illustrative example of a monastery library with a high degree of content of the $18^{\text {th }}$ century copies is the collection of the Grabovac Monastery, which has got all the types of books typical for this period.
\end{abstract}

Keywords: manuscripts, copying, monasteries, Metropolitanate of Karlovci, $18^{\text {th }}$ century, monastery libraries, manuscripts of Grabovac Monastery 

under a Creative Commons Attribution-NonCommercial-NoDerivatives 4.0 International License. 